\title{
CULTURAL PRACTICES AND GENETIC RESISTANCE AS FACTORS AFFECTING SOYBEAN STEM CANKER AND PLANT YIELD IN THE CERRADO*
}

\author{
MARCOS A. FREITAS ${ }^{1 * *}$, ADALBERTO C. CAFÉ FILHO ${ }^{1 * * *} \&$ LUIZ C. B. NASSER ${ }^{2}$ \\ 'Departamento de Fitopatologia, Universidade de Brasília, CEP 70910-970, Brasília, DF, e-mail:cafefilh@unb.br; \\ ${ }^{2}$ EMBRAPA Cerrados, CEP 73301-370 Planaltina, DF
}

(Aceito para publicação em 27/04/2001)

Corresponding author: Adalberto C. Café Filho

FREITAS, M.A., CAFÉ FILHO, A.C. \& NASSER, L.C.B. Cultural practices and genetic resistance as factors affecting soybean stem canker and plant yield in the Cerrado. Fitopatologia Brasileira 27:005-011. 2002.

\begin{abstract}
Field experiments were conducted in the 1995-96 soybean (Glycine max) growing season to evaluate the effects of cultural practices and host genetic resistance on the intensity of soybean stem canker, caused by Diaporthe phaseolorum f.sp. meridionalis (Dpm). Experiments were conducted in a commercial field severely infected in the previous (1994-95) season. In one study, minimum tillage (MT) and no-tillage (NT) cropping systems were investigated for their effects on disease development and on plant yields in cvs. FTCristalina (susceptible) and FT-Seriema (moderately resistant). Another study evaluated the effects of plant densities (8,15, 21 and 36 plants $/ \mathrm{m}$ ) on disease development in cvs. FT-Cristalina, FT-101 (moderately resistant) and FT-104 (resistant). Disease incidence and severity were consistently lower in NT than in MT, and plant yields were increased by $23 \%$ and $14 \%$ in the NT system for the

susceptible and moderately resistant cultivars, respectively, compared to the yields in the MT system. The Gompertz and Logistic models described well the disease progress curves in all situations. For both susceptible and moderately resistant cultivars, disease severity increased proportionately to the increase in plant densities. At the end of the season, $100 \%$ of the plants of $\mathrm{cv}$. FT-Cristalina were infected by Dpm, at all plant densities. Disease levels on cv. FT-101 were intermediate while only very low disease levels were recorded on cv. FT-104. There was a consistent negative correlation between stem canker severity and yield. Some practices demonstrated potential for direct application in disease control, and could be combined considering their additive effects.

Additional Key words: Glycine max, tillage, Phomopsis phaseoli f.sp. meridionalis.

\section{RESUMO \\ Influência de práticas culturais e da resistência genética na intensidade do cancro da haste e produção de soja no Cerrado}

Os efeitos de práticas culturais e resistência genética na intensidade ao cancro-da-haste da soja (Diaporthe phaseolorum f.sp. meridionalis - Dpm) foram examinados na safra 1995-96 em áreas de produção comercial, que haviam sido severamente atacadas na safra anterior (1994-95). Um experimento investigou os efeitos de cultivo mínimo (MT) e do plantio direto (NT) no desenvolvimento da doença e produtividade das cultivares FT-Cristalina e FT-Seriema. Em outro experimento, semeado em plantio direto, estudou-se o efeito da densidade de plantas $(8,15,21$ e 36 plantas $/ \mathrm{m})$ no desenvolvimento da doença e produtividade das cvs. FT-Cristalina (suscetivel), FT101 (moderadamente resistente) e FT-104 (resistente). Incidência e severidade da doença foram menores em NT do que em MT. A produtividade aumentou no sistema NT (23\% para 'FT-Cristalina' e

14\% para 'FT-Seriema'), comparada com as produtividades em MT. As curvas de progresso da doença foram melhor descritas pelos modelos de Gompertz e logístico. A severidade do cancro aumentou proporcionalmente ao aumento das densidades de plantio nas cvs. suscetível e moderadamente resistente. No final do ciclo, $100 \%$ das plantas da cv. FT-Cristalina estavam infetadas por Dpm, em todas as densidades de plantio. Níveis intermediários de doença foram observados na cv. FT-101, enquanto apenas níveis muito baixos de doença ocorreram na cv. FT-104. Estabeleceu-se uma correlação negativa entre severidade de cancro-da-haste e produção. Algumas das práticas estudadas demonstraram potential para aplicação direta no controle da doença, e poderiam ser combinadas considerando-se seus efeitos aditivos.
\end{abstract}

\section{INTRODUCTION}

\footnotetext{
*Parte da dissertação de mestrado do primeiro autor. Universidade de Brasília (1997).

** CAPES fellowship

*** CNPq fellowship
}

Soybean [Glycine max (L.) Merr.] stem canker, caused by Diaporthe phaseolorum (Cke. \& Ell.) Sacc. f.sp. meridionalis Morgan-Jones, Dpm (anamorph: Phomopsis phaseoli (Desmaz.) Sacc. f.sp. meridionalis Morgan-Jones) 
was first recorded in Brazil in the 1988/89 growing season. From 1993 to 1996 it was considered one of the main limiting factors in soybean production. Farmers in the Cerrado, a savannah-like region responsible for $c .45 \%$ of the soybean production in Brazil, have been adopting a no-tillage cropping system since the early 1980 's. Nevertheless, research on the effects of this practice has been limited, especially regarding its putative effects on plant diseases. No information on the effect of no-till practices on the development of stem canker is available for the Cerrado, although it was found that notill favored stem canker on cv. Hutton in the USA (Rothrock et al. 1985, 1988).

Published results on the effects of soybean planting densities on Diaporthe/ Phomopsis disease complex are variable. According to Bowman et al. (1986), the incidence of Phomopsis spp. in soybean seed was not influenced by row width, but Chin et al. (1993) concluded that higher plant densities favored infection by $D$. phaseolorum $\mathrm{f}$. sp. sojae (Lehman) Wehm. On the other hand, with another splashdispersed soybean pathogen, Septoria glycines Hemmi, the trend is toward a higher incidence as row width gets wider (Pataky \& Lim, 1981), especially early in the season (Mmbaga et al., 1979).

Although host resistance is probably one of the best options for stem canker control, many susceptible varieties remain in the market as they possess desirable agronomic characteristics (Backman et al., 1989). Thus, other measures, such as cultural practices, production of healthy seed, chemical control and seed treatment are necessary. Management of plant population levels and the adequate choice of cropping systems may diminish stem canker intensity on cultivars with moderate levels of resistance, and could extend the time that desirable cultivars are available each season. The aim of this study was to evaluate the effects of cultural practices and genetic resistance on the incidence and severity of soybean stem canker.

\section{MATERIALS AND METHODS}

The study on the effects of tillage and genetic resistance on soybean stem canker and plant yield was set up during the summer of 1995/96 in a commercial field with a history of stem canker. Soybean cvs. FT-Cristalina (Susceptible - S) and FT-Seriema (moderately resistant - MR) were planted following standard minimum tillage (MT) and no-tillage (NT) protocols (i.e., sown after plowing vs. directly sown on previous crop and weed debris, respectively). Natural inoculum was supplied by soybean debris from the previous season, which was observed to bear abundant pycnidia and ascocarps of the pathogen. Each experimental unit consisted of 22 rows, $10-\mathrm{m}$ in length and spaced $0.45 \mathrm{~m}$ apart, 18 plants/ $\mathrm{m}$. Cultivars represented sub-plots and cropping systems the main plots, in a split-plot design with four replicate blocks. Incidence (percentage of plants affected) and severity values of stem canker were recorded. Severity was rated on the lower third of each individual plant stem, measured according to the disease scale published by Freitas et al. (1998), in which: (1) indicates plants with no external symptoms or with stem lesions equal or less than $2 \mathrm{~mm}$; (2) stem lesions up to $5 \mathrm{~cm}$ in length; (3) lesions up to $10 \mathrm{~cm}$ in length, girdling of plant stem, sometimes also showing typical interveinal foliar symptoms (chlorosis); (4) stem lesions larger than $10 \mathrm{~cm}$, plant showing advanced interveinal foliar symptoms (necrosis); (5) dead plants. An index of disease severity was calculated using the formula $S=\sum\left(n_{i} / n_{t} \times N_{i}\right)$, where $S=$ severity index; $n_{i}=$ number of individual plants in each plot that were rated for severity note $\mathrm{Ni}$; and $\mathrm{n}_{\mathrm{t}}$ total number of plants in each plot. Measurements were made 50, 73, 96 and 136 days after seeding (DAS) when the crop was at stage V12, R1, R3 and R6 (Ritchie et al., 1982), respectively. Soybean yields were recorded by harvesting five meters of the three center rows of each plot and adjusting seed moisture to $13 \%$.

Diagnosis for stem canker was confirmed by collection of random samples of soybean plants with field symptoms during the course of the season according to Damicone et al. (1990). Pathogenicity of the isolates was tested using the toothpick method (Hildebrand, 1953). Disease progress curves were fit to the logistic, Gompertz and the monomolecular models (Campbell \& Madden, 1990) and the areas under disease progress curves (AUDPC) based on incidence and severity were compared.

The study on the effects of plant density and genetic resistance on soybean stem canker and plant yield was conducted during the summer season of 1995/96 in a commercial area previously planted with cv. FT-Cristalina which had been severely diseased. Experimental units were made up of four $4-\mathrm{m}$ rows, spaced $0.45 \mathrm{~m}$ apart. The experimental design was a factorial with two factors (cultivars and plant densities), with three cultivars with different levels of resistance: FT-Cristalina (S), FT-101 (MR) and FT-104 (R), and four planting densities: eight; 15; 21; and 36 plants/ $\mathrm{m}$. Each treatment combination was replicated five times in a randomized complete block design. The experiment was conducted under no tillage. Thinning was carried out 26 DAS in order to make plant densities uniform, according to the pre-established classes. Incidence and severity values of stem canker were recorded on all plants of the two center rows for each plot at 53, 70, 89 and 122 DAS, corresponding to soybean stages R1, R2, R3 and R5.5, respectively. The area under the disease progress curves and grain yields (adjusted to $13 \%$ moisture) were also determined. Plant height, number of pods/plant, lodging (Bernard et al., 1965) and stem diameter at harvest (at $1^{\text {st }}$ node) were also recorded on 50 randomly collected plants. Analysis of variance, separation of means and analysis of correlation were conducted using SAS software (SAS Institute, Cary, NC).

\section{RESULTS}

\section{Effects of tillage and genetic resistance on soybean stem canker and plant yield}

First symptoms of stem canker were observed at 50 
Cultural practices and genetic resistance as factors affecting soybean stem...

DAS (stage V12), as typical reddish-brown small depressions (up to $2 \mathrm{~mm}$ in diam.) and vascular discoloration. Disease incidence and severity increased with time, were lower on the MR cultivar, and were consistently lower on the NT system (Figure 1a, b). The same results were evident for the consolidated disease values of the AUDPC, calculated either as the incidence (Figure 2a) or the severity of stem canker (Figure 2b).

All progress curves based on incidence or severity (Figure 1) were well described by sigmoid models, but generally best described by the Gompertz model. Disease curves on both the $\mathrm{S}$ cultivar as well as on the MR cultivar had lower coefficient $b$ (rate of disease progress) on the NT system than in the MT system (Table 1). The monomolecular model was not adequate for describing the incidence or severity progress curves.

Grain yields were significantly $(\mathrm{P}<0.001)$ affected by degree of disease resistance and by cropping system, with greater disease and lower yield occurring on the susceptible cultivar and the MT system (Table 2).

Effects of plant density and genetic resistance on soybean stem canker and plant yield

Stem canker symptoms were first detected at 70 DAS (stage R2), when differences among cultivars were already conspicuous: disease incidence was highest in the $\mathrm{S}$ cultivar, FT-Cristalina (28\%), intermediate in the MR cultivar, FT101 (5.8\%), and lowest in the R cultivar, FT-104 (0.4\%). Severity values were low $(1.3-1.0)$, but followed the same trend, decreasing proportionally to the level of genetic resistance to stem canker. Effect of plant density on disease was not significant at 70 DAS $(\mathrm{P}>0.05)$.

A significant interaction was detected between cultivar and density $(\mathrm{P}<0.01)$ at 89 DAS (stage R3) for disease incidence, as follows: for FT-Cristalina (S), the incidence decreased with increasing plant densities (Figure 3a), while no significant trend was detected for FT-101 (MR) or FT104 (R). A similar interaction between cultivar and density was observed for the severity data: decreasing severity values with increasing plant densities for FT-Cristalina $(\mathrm{P}<0.05)$, but no consistent trends for the other cultivars (Figure $3 b$ ).

At the last evaluation, 122 DAS (stage R5.5), all plants of cv. FT-Cristalina, at all planting densities were infected, and disease incidence decreased proportionally to the level of genetic resistance to stem canker (Figure 4a). At this growth stage, the severity of stem canker increased with increasing plant densities for FT-Cristalina (S) and FT-101 (MR), while no trend was detected for R cultivar, FT-104 (Figure 4b).

The results of the consolidated data represented by the AUDPCs confirmed the same trends (Figure $5 \mathrm{a}, \mathrm{b}$ ). Generally, for all cultivars, a progressive trend towards the reduction in incidence with increasing plant densities was found from eight to $21 \mathrm{plants} / \mathrm{m}$. However, when the AUDPC was calculated as a function of severity data, the reverse was found: for all cultivars, disease was most severe with 36 plants $/ \mathrm{m}$.

A high negative correlation $(\mathrm{P}<0.001)$ was observed
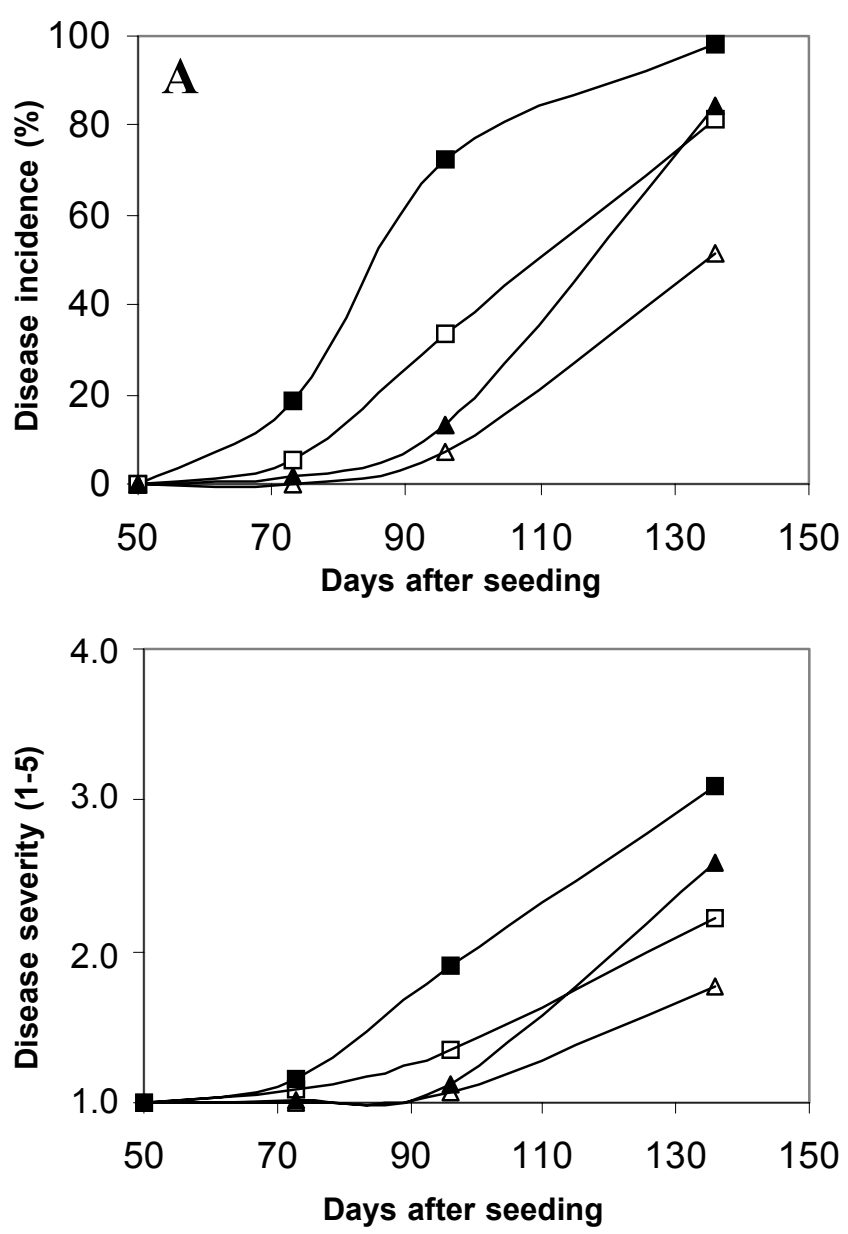

FIG. 1 - Disease progress curves of the incidence (A) and severity (B) of soybean stem canker on susceptible FT-Cristalina and mod. resistant FTSeriema cultivated on minimum tillage (MT) or no tillage (NT) cropping systems. Black and white squares show disease curves on FT-Cristalina on MT or NT systems, respectively. Black and white triangles show equivalent treatments for FTSeriema.

between grain yield and the incidence $(\mathrm{R}=-0.82)$ or severity $(\mathrm{R}=-0.90)$ of stem canker, as measured from the AUDPCs consolidated values. Grain yield and number of pods per plot decreased strongly and progressively with decreasing levels of disease resistance $(\mathrm{P}<0.05)$. There was no interaction $(\mathrm{P}>0.05)$ between cultivar and plant density for yield variables (data not shown).

Plant density also affected other agronomic variables, such as stem diameter and lodging. Stem diameter was significantly $(\mathrm{P}<0.001)$ reduced with increasing densities. Lodging increased progressively from 1.5 to 5.0 for FTCristalina, 1.0 to 2.6 for FT-101, and from 1.0 to 3.7 for FT104 when densities were increased from eight to 36 plants/ $\mathrm{m}$. Correlation between plant densities and lodging was significant $(\mathrm{R}=0.79, \mathrm{P}<0.001)$. 
TABLE 1 - Parameters of the linear regressions of the stem canker progress curves in susceptible and moderately resistant soybean (Glycine max) cultivars FT-Cristalina and FTSeriema seeded in the no-till (NT) or minimum tillage (MT) systems according to the Gompertz model

\begin{tabular}{|c|c|c|c|c|c|c|}
\hline \multirow[b]{2}{*}{$\begin{array}{l}\text { Variable and } \\
\text { Cultivar }\end{array}$} & \multirow{2}{*}{$\begin{array}{c}\text { Planting } \\
\text { system }\end{array}$} & \multicolumn{2}{|c|}{ Parameter $^{2}$} & \multirow[b]{2}{*}{$\mathbf{R}^{2}$} & \multirow[b]{2}{*}{ MSE } & \multirow[b]{2}{*}{$\mathbf{P}$} \\
\hline & & $\begin{array}{c}-\ln \left(-\ln \left(y_{0}\right)\right) \\
\text { (a) }\end{array}$ & $\begin{array}{c}\mathrm{R} \\
\text { (b) }\end{array}$ & & & \\
\hline \multicolumn{7}{|c|}{ Disease Incidence Progress Curves } \\
\hline \multirow[t]{2}{*}{ FT-Cristalina ${ }^{\mathrm{x}}$} & MT & $-6.07 c$ & $0.076 \mathrm{a}$ & 0.97 & 0.237 & 0.0001 \\
\hline & NT & $-4.29 a$ & $0.043 \mathrm{bc}$ & 0.99 & 0.021 & 0.0001 \\
\hline \multirow[t]{2}{*}{ FT-Seriema ${ }^{y}$} & MT & $-5.07 b$ & $0.049 \mathrm{~b}$ & 0.93 & 0.196 & 0.0001 \\
\hline & NT & $-4.21 \mathrm{a}$ & $0.033 \mathrm{c}$ & 0.92 & 0.109 & 0.0001 \\
\hline \multicolumn{7}{|c|}{ Disease Severity Progress Curves } \\
\hline \multirow[t]{2}{*}{ FT-Cristalina ${ }^{\mathrm{x}}$} & MT & $-1.711 \mathrm{c}$ & $0.0034 \mathrm{a}$ & 0.96 & 0.0004 & 0.0001 \\
\hline & NT & $-1.664 b$ & $0.0023 \mathrm{c}$ & 0.94 & 0.0004 & 0.0001 \\
\hline \multirow[t]{2}{*}{ FT-Seriema ${ }^{y}$} & MT & $-1.707 \mathrm{c}$ & $0.0028 \mathrm{~b}$ & 0.82 & 0.0020 & 0.0001 \\
\hline & NT & $-1.631 \mathrm{a}$ & $0.0016 \mathrm{~d}$ & 0.81 & 0.0007 & 0.0001 \\
\hline
\end{tabular}

${ }^{x}$ Susceptible cultivar.

${ }^{\mathrm{y}}$ Moderately resistant cultivar.

${ }^{z}$ Values followed by the same letter are not significantly different, according to the Student ' $t$ ' test, $\alpha=0.05$.

\section{DISCUSSION}

Results consistently showed that adoption of the NT cropping system in the Cerrados resulted in lower stem canker intensity. This is contrary to the data of Rothrock et al. (1985, 1988) in the southern part of the USA, who isolated the pathogen (southern biotype) more frequently from plants cultivated in the NT system than in the MT system. Differences could be due to interactions of soil, climate, biological environment, cultivar, isolate biotype, and to the dispersion barrier provided by the weed debris on the NT system. Backman et al. (1985) and Smith \& Backman (1988) recommended late seeding for stem canker control, in order to allow enough time to pass to exhaust the pathogen spore load (corresponding to the initial inoculum), produced in the beginning of the rainy season. In the Cerrado however, the inoculum left in the field was sufficient for $100 \%$ infection of the susceptible cultivar. This was true in spite of late planting (December) and the occurrence of significant rains before the planting dates, indicating that the plowing carried out in the MT was not sufficient to effectively reduce the initial inoculum. It was evident that soybean debris was not totally buried by cultivation. More importantly, with the lack of soil mulch in MT, the rain drops were probably more efficient in dispersing the pathogen propagules, since no cover crop was superposed over the previous season's soybean debris. In contrast, the NT system provided a blanket over debris that likely reduced the impact of rain on the spore masses, resulting in less dispersion of inoculum. Heavy weed infestation (mainly Bidens pilosa L.) was originally present at the beginning of the planting season. Moreover, reduction of Dpm dispersion by use of millet [Pennisetum glaucum (L.) R.Br.] as cover crop has been recorded by Yorinori (1996). Conversely, using conventional tillage in the Cerrado, dispersion of Dpm from single point foci was determined to be significant: an average
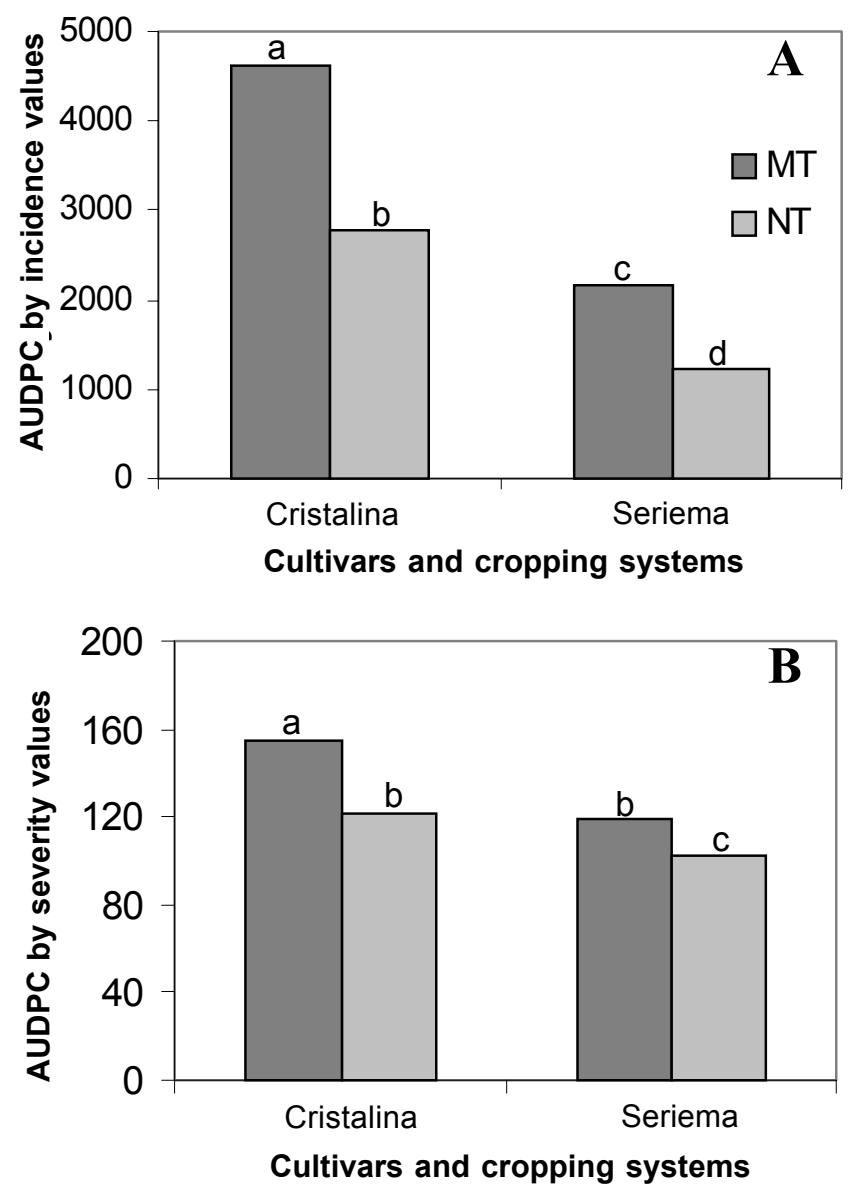

FIG. 2 - Area under disease progress curves (AUDPC) measured by the incidence (A) and the severity (B) of soybean (Glycine max) stem canker on susceptible cv. FT-Cristalina and moderately resistant cv. FT-Seriema, cultivated under minimum tillage (MT) and no-tillage (NT) cropping systems.

of $32 \mathrm{~m}^{2}$ of soybean plants were infected from one focal point of Dpm (Freitas et al., 1998).

Variable levels of field resistance to stem canker were discriminated in both field trials and disease intensity was

TABLE 2 - Mean yield of soybean (Glycine max) cultivars planted in minimum tillage (MT) and no tillage (NT) cropping systems

\begin{tabular}{|c|c|}
\hline Cultivar and cropping system & Yield (Kg/ha) ${ }^{\mathrm{z}}$ \\
\hline FT-Cristalina ${ }^{\mathrm{x}} \mathrm{MT}$ & $1,454 \mathrm{a}$ \\
\hline FT-Cristalina ${ }^{\mathrm{x}}$ NT & $2,020 \mathrm{bc}$ \\
\hline FT- Seriema ${ }^{\mathrm{y}} \mathrm{MT}$ & $1,977 \mathrm{~b}$ \\
\hline FT- Seriema ${ }^{\mathrm{y}}$ NT & $2,298 \mathrm{c}$ \\
\hline
\end{tabular}

${ }^{\mathrm{x}}$ Susceptible cultivar.

${ }^{y}$ Moderately resistant cultivar.

$\mathrm{z}$ Values followed by the same letter are not significantly different, according to Tukey's test for mean comparison, $\alpha=0.05$. 
Cultural practices and genetic resistance as factors affecting soybean stem...
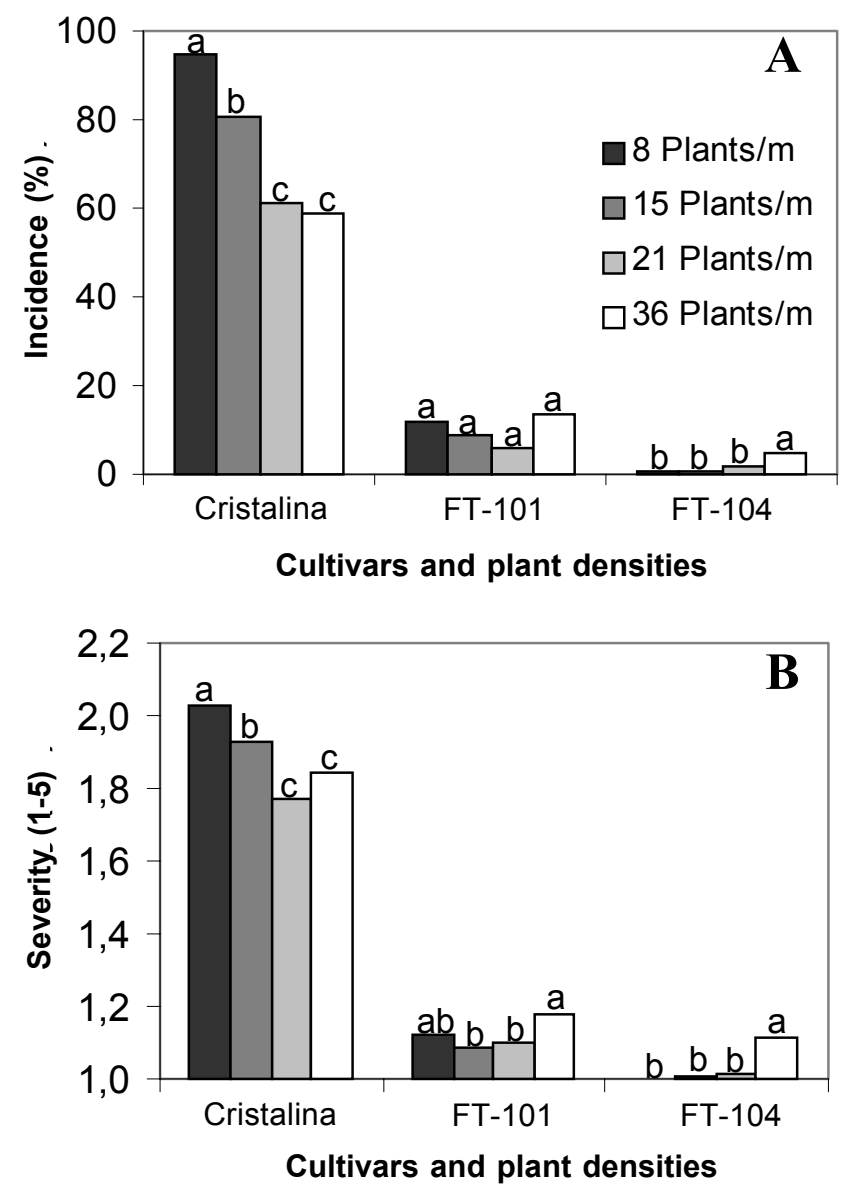

FIG. 3 - Incidence (A) and severity (B) of soybean (Glycine max) stem canker in cvs. FT-Cristalina, FT-101 and FT-104 in plant densities 8, 15, 21 and 36 plants/m, 89 days after seeding (stage $R 3$ ). Cultivar differences were significant $(P<0.05)$. Letters indicate comparison among plant densities within cultivars (Tukey, $\alpha=\mathbf{0 . 0 5}$ ).

effectively reduced with resistance. This corroborates the practical use of the genetic resistance already identified in the germplasm of soybean (Yorinori, 1996). Nevertheless, all four cultivars, even the most resistant, were infected by Dpm. On the other hand, when genetic resistance was combined with specific plant densities, or tillage systems, additional gains in control were observed, which were reflected in better yields. According to Ploetz \& Shokes (1985) and Rothrock et al. (1988) frequency of seedling infection by $D$. phaseolorum was the same for all soybean cultivars, irrespective of their resistance level. This was not verified in this study: infection (as measured by disease incidence) was reduced with genetic resistance, but severity was even further reduced, suggesting that mechanisms of resistance prior to and following infection play additive roles. The measurement of severity values provided evidence that at initial stages (notes 1-2) there is little injury to the host, and thus, in consequence, severity was a better predictor of yield than incidence.

The epidemiological effects of genetic resistance on


FIG. 4 - Incidence (A) and severity (B) of soybean (Glycine max)stem canker on cvs. FT-Cristalina, FT-101 and FT-104 in plant densities 8, 15, 21 and 36 plants/m, 122 days after seeding (stage $R$ 5.5). Letters on the severity graph indicate comparison among plant densities, within cultivars (Tukey, $\alpha=$ 0.05). There were no significant incidence differences at this stage for plant densities within cultivars.

disease progress studied before are in agreement with the results presented here. In spite of the monocyclic nature of the disease, the Gompertz model fitted best the pattern of all disease progress curves. This can be attributed to the correlation between time of symptom expression and plant growth (which naturally follows a sigmoid pattern). Damicone et al. (1990) and Subbarao et al. (1992) also found that sigmoid models described stem canker progress well, and Linders et al. (1995) found similar results for a related pathogen, Diaporthe adunca (Rob.) Niessl in populations of Plantago lanceolata L. Disease symptoms started late in the season. This is usually observed in the soybean-Dpm pathosystem: many authors (Hildebrand, 1956; Damicone et al., 1987; Damicone et al., 1990; Bowers et al., 1993) reported that although plants may be infected earlier in the season, disease symptoms appear in the reproductive phase. On the other hand, Yorinori (1996) noted stem canker symptoms as 
M.A. Freitas et al.

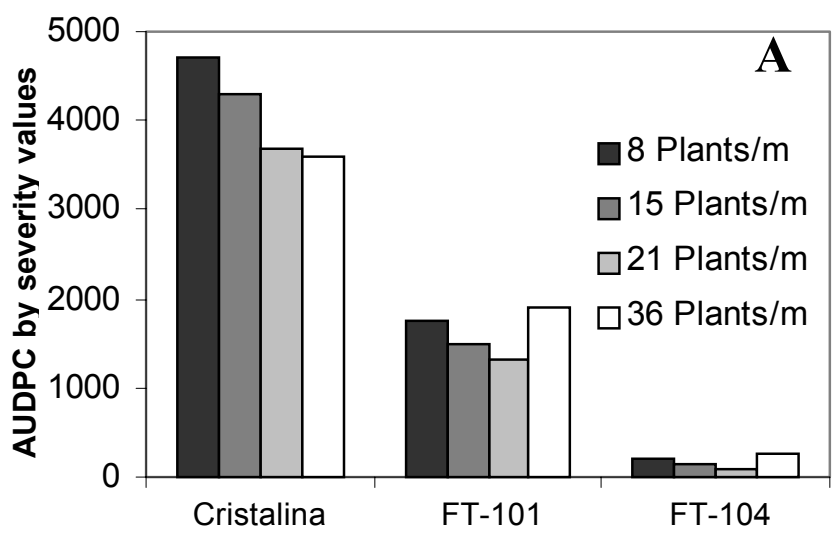

Cultivars and plant densities



FIG. 5 - Area under disease progress curves measured by the incidence (A) or the severity (B) of soybean (Glycine max) stem canker in different soybean cultivars and plant densities. Letters on the severity graph indicate comparison among plant densities within cultivars (Tukey, $\alpha=0.05$ ). There were no significant incidence differences at this stage for plant densities within cultivars.

early as 20 days after emergence.

Plant density affected disease significantly. Incidence was lower with higher densities at 89 DAS (Figure 3a), because plant stems initially functioned as physical barriers to the rain-splashed ascospores, but this trend disappeared later at 122 DAS (Figure 4a). Severity, on the other hand, seemed to increase with density, indicating that the microenvironment under the plant canopy was more conducive to disease with increasing densities. Smaller stem diameters and more severe lodging associated with higher densities also probably played important roles in favoring disease, although the influence of plant density on lodging was likely compounded in cv. FT-Cristalina (which had the highest lodging values) due to its higher susceptibility to stem canker. The consolidated effect of higher plant densities was an increase in disease intensity (the combination of incidence and severity), agreeing with results of a previous study on this pathosystem (Chin et al., 1993). This contrasts with data from lesions caused by a related soybean pathogen (Septoria glycines Hemmi), where infections seem to increase with wider row widths (Mmbaga et al., 1979; Pataky \& Lim, 1981).

Even though stem canker is no longer a major problem due to the increasing availability of resistant cultivars, the agronomic practices studied demonstrated potential in reducing stem canker damage, and may be employed in IPM approaches towards the control of the disease in the Cerrado region.

\section{ACKNOWLEDGMENTS}

We thank Antonio Carlos Gomes for help with the statistical analysis.

\section{LITERATURE CITED}

BACKMAN, P.A., McGEE, D.C., MORGAN-JONES, G. Stem canker. In: Sinclair J.B. \& Backman P.A. (Eds.). Compedium of Soybean Diseases. St. Paul. The American Phytopathology Society. $3^{\text {rd }}$. ed. 1989. pp. 41-43.

BACKMAN, P.A., WEAVER, D.B. \& MORGAN-JONES, G. Soybean stem canker: An emerging disease problem. Plant Disease 69:641-647. 1985.

BERNARD, R.L., CHAMBERLAIN, D.W. \& LAWRENCE, R.E. Results of the Cooperative Uniform Soybean Tests. Washington, DC: USDA. 1965.

BOWERS Jr., G.R., NGELEKA, K. \& SMITH, O.D. Inheritance of stem canker resistance in soybean cultivars Crockett and Dowling. Crop Science 33:67-70. 1993.

BOWMAN, J.E., HARTMAN, G.L., McCLARY, R.D., SINCLAIR, J.B., HUMMEL, J.W. \& WAX, L.M. Effects of weed control and row spacing in conventional tillage, reduced tillage, and nontillage on soybean seed quality. Plant Disease 70:673-676. 1986.

CAMPBELL, C.L. \& MADDEN, L.V. Introduction to Plant Disease Epidemiology. Wooster. Wiley-Interscience. 1990.

CHIN, M.S., KIM, S.H. \& PARK, W.M. Effect of planting date, plant density, nitrogen level, harvest date and benomyl treatment on Diaporthe phaseolorum var. sojae infection and germination of soybean seeds. Journal of Agricultural Science 35:99-108. 1993.

DAMICONE, J.P., BERGGREN, G.T. \& SNOW, J.P. Effect of free moisture on soybean stem canker development. Phytopathology 77:1568-1572. 1987.

DAMICONE, J.P, SNOW, J.P. \& BERGGREN, G.T. Spatial and temporal spread of soybean stem canker from an inoculum point source. Phytopathology 80:571-578. 1990.

FREITAS, M.A., CAFÉ FILHO, A.C. \& NASSER, L.C.B. Gradientes do cancro da haste da soja (Diaporthe phaseolorum f.sp. meridionalis) a partir de foco pontual de inóculo. Fitopatologia Brasileira 23:161-165. 1998.

HILDEBRAND, A.A. An elaboration of the toothpick method of inoculating plants. Canadian Journal of Agricultural Science 33:596-508. 1953.

HILDEBRAND, A.A. Observations on stem canker and pod and stem blight of soybeans in Ontario. Canadian Journal of Botany 34:357-599. 1956.

LINDERS, E.G.A., Van DAMME, J.M.M. \& ZADOKS, J.C. 
Epidemics of Diaporthe adunca in experimental and in natural populations of Plantago lanceolata and the effect of partial resistence on disease development. Plant Pathology 45:70-83. 1995.

MMBAGA, M.T., GRAY, C.R. \& ARNY, D.C. Septoria brown spot of soybeans: Effect of row width and tillage practice on disease development. Phytopathology 69:541. 1979. (Abstract).

PATAKY, J.K. \& LIM, S.M. Effects of row width and plant growth habit on Septoria brown spot development and soybean yield. Phytopathology 71:1051-1056. 1981.

PLOETZ, R.C. \& SHOKES, F.M. Factors influencing infection of soybean seedlings by Southern Diaporthe phaseolorum. Phytopathology 77:786-790. 1987.

PLOETZ, R.C. \& SHOKES, F.M. Soybean stem canker incited by ascospores and conidia of the fungus causing the disease in the southeastern United States. Plant Disease 69:990-992. 1985.

RITCHIE, S.W., HANWAY, J.J. \& THOMPSON, H.E. How a Soybean Plant Develops. Iowa State Univ. of Science and Technol. Coop. Ext. Serv. Special Report no 53. 1982.

ROTHROCK, C.S., HOBBS, T.W. \& PHILLIPS, D.V. Effects of tillage and croping system on incidence and severity of southern stem canker of soybean. Phytopathology 75:1156-1159. 1985.

ROTHROCK, C.S., PHILLIPS, D.V. \& HOBBS, T.W. Effects of cultivar, tillage and croping system on infection of soybean by Diaporthe phaseolorum var. caulivora and southern stem canker of soybean. Phytopathology 78:266-270. 1988.

SMITH, E.F. \& BACKMAN, P.A. Soybean stem canker: An overview. In: Willie, T.D. \& Scott, D.H. (Eds.). Soybean Diseases of North Central Region. St. Paul. The American Phytopathological Society. 1988. pp.47-55.

SMITH, E.F. \& BACKMAN, P.A. Epidemiology of soybean stem canker in the Southeastern United States: Relationship between time of exposure to inoculum and disease severity. Plant Disease 73:464-468. 1989.

SUBBARAO, K.V., SNOW, J.P., BERGGREN, G.T., DAMICONE, J.P. \& PADGETT, G.B. Analysis of stem canker epidemics in irrigated and nonirrigated conditions on differentially susceptible soybean cultivars. Phytopathology 82:1251-1256. 1992.

YORINORI, J.T. Cancro da haste da soja: epidemiologia e controle. Londrina. Embrapa-Soja. Circular Técnica no. 14. 1996. 